\title{
The Critical Epistemology of Paulo Freire
}

\author{
James M. Czank \\ Lakehead University, Canada
}

\begin{abstract}
My paper is an exploration of the notion of critical consciousness in Freire's philosophy of praxis. The underlying "so what?" for this paper is what Freire recognized as the problem of people only absorbing the substance of his philosophy to a certain degree, resulting in a definitive movement away from a critical embracement of change and an assumption of positions that he considered antiFreirean in nature [1]. Another, and not unrelated, reason for a paper such as this is what McLaren heralds as contemporary revisionism, which, he maintains, antiseptically excises the corporeal force from Freire's practice through the diversification of its Marxist elements [2]. McLaren attributes this to the 'post' times we live under, which places under suspicion master narratives, universalism, and objectivity [3]. The importance of this paper lay in the light it sheds on Freire's epistemological commitments, and the query it raises about the nature of his philosophy. I also include a brief exegesis of the philosophy of Freire.
\end{abstract}

\section{Introduction}

It was Freire's conviction that the world could be a less ugly, less discriminatory, less dehumanizing, and more beautiful, more democratic, and a more humane place, which first endeared the man and his writing to me. And it was the following passage from his "Education for Critical Consciousness":

The more accurately men [sic] grasp true causality, the more critical their understanding of reality will be... critical consciousness always submits that causality to analysis; what is true today may not be so tomorrow. Naïve consciousness sees causality as a static, established fact, and thus is deceived in its perception. [4]

...that got me wondering about the nature of his philosophy, since it does not really fit with the dialectical materialism that, I have been told, defines Freire.

My investigation confirmed what I already knew about Freire, that his philosophy is indivisible from history, dialecticism, and the world. It also turned up a little something about the scholarship surrounding the man and his ideas; it seems that a great deal of the scholarship, coming from people like Ronald Glass [5], Peter McLaren [6] [7] [8], and Wayne Au [9], is about the dialectical materialism of Freire.

I also had the incongruity of his epistemology addressed. According to Carlos Alberto Torres, to understand Freire one needs to appreciate how he uses two different - but linked - lines of theoretical development: One is the dialectical perspective that emphasizes the histories of individuals and structures in the production of the material and symbolic layers of human life, id est dialectical materialism; and the other is his ever evolving theory of critical agency [10], expressed in passages like the one that set me upon this investigation, and in statements like:

[Critical consciousness] enrolls [people] in the search for self-affirmation... the awakening of critical consciousness leads the way to the expression of social discontents precisely because these discontents are real components of an oppressive situation. [11]

I found Torres' identification of the different lines of theoretical development validating, as it confirms that Freire's philosophy extends beyond the idea and label of dialectical materialism. In fact, further investigation showed that critical consciousness cannot be reduced to a chronological conversion of consciousness at all [12]... nor, to paraphrase Freire, can it be reduced to a shadow of his materialism [13]. So what is this element of critical consciousness?

\section{Analysis}

Freire believed consciousness to be something involved both in and with the world. This notion of existing "in" the world suggests a fairly standard individual and determinate view of consciousness. Existing "with" the world rounds the idea of consciousness out. "With" is plural in nature wherein consciousness is organized in necessitudinem. Freire treats consciousness in much the same manner as Hegel and Marx treated it, as a third person reflexsive pronoun, i.e. as something neutral that covers all genders. "In" and "with" is how Freire describes consciousness; consciousness, 
for Freire, is our relating to the world in a meaningful way.

Freire defines critical consciousness as analysis and as a rigorous reading of the world; or, as he explains it...

[a] way to understand better the problem of interests [and] the questions of power. How to get power [and] what it means not to have power. Finally, [it] implies a deeper reading of reality, [and that] common sense goes beyond the common sense. [14]

It is to bring an element of understanding to the "in" and "with" that is his notion of consciousness. Like dialectical materialism, critical consciousness has to do with the relationship between subject and object; but it also has to do with self-consciousness, the relationship between the theoretical and the practical, and it constitutes the link between ego and desire that fueled Freire's struggle of and for the oppressed [15]. Its standpoint, as something distinct from but linked to dialectical materialism, is the relation individuals have to the rest of the world as an engaged consciousness, accorded to a notion of dialectics, dialogue, and praxis. The idea of engagement is crucial to Freire's notion of critical consciousness, as it is how he believes we create reality and are able to add to the world in an authentic way [16] - how we 'keep it real.' As such, I appreciate Torres' reference to a critical theory of agency (rather than consciousness) in describing the two lines of Freire's theoretical development, because agency emphasizes a level of engagement not typically associated with consciousness, which is fundamental to Freire's stance.

For Freire, the idea of critical consciousness arises as an antinomy in understanding to, what he calls, naïve consciousness and magical consciousness. The latter of these two, id est magical consciousness ${ }^{1}$, represents a failure to appreciate causality, or as Freire explains it, the failure to recognize our agency in the world [17]. It is a categorization of those who adapt themselves defenselessly and passively to the expectations of a superior force, people who accept life for what it is and do not question the injustices done to them [18]. It is also to treat human awareness as an empty space waiting for content - thus begging the question of whose content, and on behalf of whom, against whom, and in favor of what, and against what [19]; remember that, according to Freire, neutrality is a myth. Magical consciousness is a representation of

\footnotetext{
${ }^{1}$ I know of at least one popular educator who refers to magical consciousness as a fatalistic consciousness because he recognizes the problematic ethic stemming from Freire's ethos of Catholicism.
}

the silent, docile, adaptive and passive position Freire was so opposed to, characterized by the sort of fatalism that leads people to fold their arms, resigned to the impossibility of resisting power [20]. It is the sort of fatalism that leaves no place for utopia [21].

The other of Freire's antinomies concerns naïve consciousness; the opposite of the fatalism I just described, Freire uses it as a categorization of those who believe themselves superior to their reality, in control of it, and thus free to understand it as they please. It is the belief that one can superimpose oneself upon the world, instead of understanding oneself as part of it [22]. Freire does not give a lot of explicit context for this, but he does refer to Hegel a lot, thus I feel justified in turning to Hegel myself. In "The Encyclopaedia Logic" Hegel explains that to be naïve is to regard the world as mere appearance, and thus fail to realize a substantive connection with it [23]. Such a determination of understanding proves trivial because of the limited nature of what it can affirm - which is not much, as all it can advance is opinion. As such, naïveté makes cognition an empty thing. Freire erects his philosophy antinominically to both of these methods of understanding the world. Remember that the point is to read the world along with the word. Drawing from Hegel, he operates from the position that our experience in and with the world is the only basis for cognition. Critical consciousness subjects the validity of our understanding to investigation, considering it according to the dialectical interplay between our selves and the world [24]. It is a process that enables its subjects or agents to critically decipher their situation or situations [25].

Thus, to be critically conscious is to have a true grasping of causality; it is, in words of Freire, to understand things and facts as they exist empirically in their causal and circumstantial correlations [26]. This is why a critical consciousness arises as an antinomy to the naïve and the fatalism inherent to the magical. This is its dynamism and transformative nature. And this is why it represents the most genuine of movements, because it is mediation between consciousness and our empirical moment, which takes place within the realm of possibility that exists before us. Ira Shor, in unembellished style, describes it as reflective distance from our own thought, action, and society. It is the separating of our consciousness from the dominant ideology socializing us in mass culture, daily life, and school [27]. When Freire says that to be critically consciousness

[...is to] enter reality [and] increase [our] capacity to make choices (and therefore [our] capacity to reject the prescription of others)... [an] imperative for those who 
believe that the destiny of [humanity] is to become authentic human beings. [28]

...he is referencing, by means of a critical understanding, a very characteristically Freirean process in which the weakness of the oppressed turns into a strength [29], a process tied to an insistence on authenticity. And if you are wondering about the idea of authenticity, a basic and easily understandable definition is by a medical doctor out of Vancouver... Gabor Maté uses it to refer to the reality behind the roles, labels, and carefully honed personae and representations of our world [30]. So, what is critical consciousness? It is an emancipating process of reflection, and the basis of Freire's philosophy.

\section{The Philosophy Behind It All}

To understand these sorts of idea, it is important to have at least an inkling of what informs them. It is quite apparent that Freire understood Western philosophy, specifically a couple of now (in)famous German fellows named Karl Marx and Georg Wilhelm Friedrich Hegel. My reading of Freire works from my understanding of these two philosophers.

When I say Freire works from Marx, I am speaking of a very Erich Frommian ${ }^{2}$ understanding of the man. It is the idea that Marx was primarily a philosopher with a concern for the emancipation of humanity, with the overcoming of human alienation, and with the restoration of human capacity to relate itself fully to its species and to its nature. This makes Marxism a philosophy that lends our existence a sense of depth, with ideas that correlate with some very non-materialistic, non-positivistic, and very philosophical sources (with the qualification that we are discussing philosophy that lifts metaphysical veils) [31]. In such a sense, human consciousness becomes a truth reflected in history rather than an abstract concept. It, for Marx, like it is for Freire, becomes more than a simple expansion and elaboration of the fulfillment of our corporeal needs, it becomes a non-abstract and constitutive essence and the genus of humankind - in the words of Marx: das menschliche Wesen.

As a philosophy Marxism is so much more than a systematic unpacking and articulation of beliefs about a materialist world and human destiny in it, and much more than a philosophy of social analysis and revolution furnishing a theory of economy and materialism. The Marx Freire

\footnotetext{
2 See Erich Fromm “Marx's Concept of Man,” Frederick Ungar Publishing Co., New York, 1971.
}

understood was more than a rigid dogmatist of class warfare and the hero of Soviet totalitarianism, that some tend to portray him as, thus so too is Freire (you can probably disregard the Soviet totalitarianism part - I cannot recall anyone making that particular claim of Freire).

For both Marx and Freire, it is impossible to understand the theorist or their conceptions and ideas (in the case of Marx specifically, this includes his notions of socialism and even his criticism of capitalism) except on the basis of the concept of humanity. The Marx Freire drew from spoke - in very philosophical language - of the importance of developing fully developed human consciousness, the full development of the humanity, and of humanity's necessity to develop itself; even Marx's criticism of capitalism centers on its destruction of individual personality and its alienating effects. So too does Freire's. The raison d'être of Marx's philosophy is the complete return of one to oneself as a human being [32] - and so too is it the raison d'être of Freire (I do not see either philosophy making any sense any other way).

And there is Hegel, who not only provides the basis for Freire's philosophy of intersubjectivity, but also the basis for Freirean concepts like actuality, and the dialectical system of genuine movement, in which the essential and the empirical moments mediate one another, that Freire employs. For Hegel and Freire (and Marx) consciousness, at its best, is the essential realm of possibility that lies before us. Emil Fackenheim provides a useful analogy for understanding this, he writes: "Providence governs the world, and the world is the place where... providence may be recognized" [33]. The idea is that we manifest what is essential about us through worldly events, and for all 'our' philosophers that which has to do with mere existence, the contingent and the adventitious, that which does not manifest the essential, is something less, something abstracted from our true nature and from the possibilities that stand before us. It's a process of giving true content to form.

The Hegelianism that Freire drew from is a philosophy that advocates finding the strength to allow the principle of subjectivity to attain the truth of its personal particularity. Subjectivity, in such a sense, is not that of abstract liberalism, but represents a substantial and ethical unity between people, it is an identity in difference, and it arises in opposition to the dearth of unity expressed by liberal individualism (or Capitalism), and the lack of individuality entailed by indifferent totalitarian identity(s).

For Hegel, and for Marx, and it follows, for Freire, what all of this comes down to is freedom. 
But not freedom in an empty liberal sense, but as it occurs in accordance with our capacity to exist, its consciousness availed of in action. For me, at least, this seems to make a lot of sense, for freedom can only make sense as the actualization of our capacity for rational self-determination within a concrete context [34]. Another way of thinking of this is freedom as the realization of our critical capacity for subjective determination. Allan Wood says that in this line of philosophy freedom represents the essence of the self to be actualized [35]. All of this, all of Marx and Hegel, is contained within the theorizing of Freire, and it is only by appreciating it that we can appreciate the man's depth.

\section{Conclusion}

In such a limited space as this paper I cannot hope to make all the connections between Freire and his German predecessors (and perhaps my argument requires that I do), and I cannot hope to provide a categorical statement about his notion of critical consciousness. I offer a different reading of Freire from many (different from some fairly prominent thinkers); I concentrate upon his philosophical side. And whether I have Freire right or I have Freire wrong, what I do provide is an opportunity to advance the conversation about Freire and his ideas, thus deepening our understanding. Which, according to Wayne Au, enables us to more successfully apply Freire's conception of critical pedagogy [36].

\section{References}

[1] P. Freire, “A Response,” in P. Freire, J.W. Fraser, D. Macedo, T. McKinnon \& W.T. Stokes (Eds.), Mentoring the Mentor: A Critical Dialogue with Paulo Freire, Peter Lang, New York, 1997.

[2] P. McLaren, "Che Guevara, Paulo Freire, and the Politics of Hope: Reclaiming Critical Pedagogy,” Cultural Studies - Critical Methodologies, 01(01), Sage, Thousand Oaks CA., 2001, pp.108-131.

[3] P. McLaren, Che Guevara, Paulo Freire, and the Pedagogy of Revolution, Rowman \& Littlefield Publishers, Lanham MD., 2000.

[4] P. Freire, Education for Critical Consciousness, The Continuum International Publishing Group Inc., New York, 1974.

[5] R.D. Glass, "On Paulo Freire's Philosophy of Praxis and the Foundations of Liberation Education," Educational Researcher 30(02), Sage, Thousand Oaks CA., 2001, pp.15-25.

[6] P. McLaren, "Che Guevara, Paulo Freire, and the Politics of Hope: Reclaiming Critical Pedagogy,” Cultural Studies - Critical Methodologies, 01(01), Sage, Thousand Oaks CA., 2001, pp.108-131.
[7] P. McLaren, Che Guevara, Paulo Freire, and the Pedagogy of Revolution, Rowman \& Littlefield Publishers, Lanham MD., 2000.

[8] P. McLaren, "A Pedagogy of Possibility: Reflecting upon Paulo Freire's Politics of Education,” Educational Researcher 28(2), Sage, Thousand Oaks CA., 1999, pp.4956.

[9] W. Au, "Epistemology of the Oppressed: The dialectics of Paulo Freire's Theory of Knowledge," Journal for Critical Education Policy Studies 05(02), The Institute for Education Policy Studies, http://www.ieps.org.uk/, 2007. Retrieved online: http://www.jceps.com/?pageID=article\&articleID=100.

[10] C.A. Torres, "Education and the Archeology of Consciousness: Freire and Hegel,” Educational Theory 44(4), University of Illinois, Urbana IL., 1994, pp.429-445.

[11] P. Freire, Pedagogy of the Oppressed, The Continuum International Publishing Group Inc., New York, 1993.

[12] C.A. Torres, "Education and the Archeology of Consciousness: Freire and Hegel," Educational Theory 44(4), University of Illinois, Urbana IL., 1994, pp.429-445.

[13] P. Freire, Pedagogy of Hope, The Continuum International Publishing Group Inc., New York, 1992.

[14] P. Freire, quoted in C.A. Torres, "Education and the Archeology of Consciousness: Freire and Hegel," Educational Theory 44(4), University of Illinois, Urbana IL., 1994, pp.429-445.

[15] C.A. Torres, "Education and the Archeology of Consciousness: Freire and Hegel," Educational Theory 44(4), University of Illinois, Urbana IL., 1994, pp.429-445.

[16] P. Freire, Education for Critical Consciousness, The Continuum International Publishing Group Inc., New York, 1974.

[17] P. Freire, Education for Critical Consciousness, The Continuum International Publishing Group Inc., New York, 1974.

[18] C. Fritze, The Theory of Paulo Freire, no date. Retrieved online: http://www.communityworktraining.org.uk/freire/.

[19] P. Freire, Pedagogy of Hope, The Continuum International Publishing Group Inc., New York, 1992.

[20] P. Freire, Education for Critical Consciousness, The Continuum International Publishing Group Inc., New York, 1974.

[21] P. Freire, Pedagogy of Hope, The Continuum International Publishing Group Inc., New York, 1992.

[22] P. Freire, Education for Critical Consciousness, The Continuum International Publishing Group Inc., New York, 1974. 
[23] G.W.F. Hegel, The Encyclopaedia Logic, Hackett Publishing, Cambridge, 1991.

[24] G.W.F. Hegel, The Encyclopaedia Logic, Hackett Publishing, Cambridge, 1991.

[25] P. Freire, Pedagogy of Hope, The Continuum International Publishing Group Inc., New York, 1992.

[26] P. Freire, Education for Critical Consciousness, The Continuum International Publishing Group Inc., New York, 1974.

[27] Shor, I. \& Freire, P. (1987). A Pedagogy for Liberation: Dialogues on Transforming Education, Bergin \& Garvey, Westport Connecticut, 1987.

[28] P. Freire, Education for Critical Consciousness, The Continuum International Publishing Group Inc., New York, 1974.

[29] P. Freire, Pedagogy of Hope, The Continuum International Publishing Group Inc., New York, 1992.

[30] G. Maté, In the Realm of Hungry Ghosts, Vintage Canada, Toronto, 2008.

[31] J. Czank, "On the Origin of Species-Being: Marx Redefined," Rethinking Marxism: A Journal of Economics, Culture, \& Society 24(2), Taylor \& Francis, Abingdon U.K., 2012, pp.316-323.

[32] E. Fromm, Marx's Concept of Man, Frederick Ungar Publishing Co., New York, 1971.

[33] E. Fackenheim, The Religious Dimension in Hegel's Thought, Beacon Press, Boston, 1967.

[34] G.W.F Hegel, Elements of the Philosophy of Right, Cambridge University Press, New York, 1991.

[35] A. Wood in G.W.F Hegel, Elements of the Philosophy of Right, Cambridge University Press, New York, 1991.

[36] W. Au, "Epistemology of the Oppressed: The dialectics of Paulo Freire's Theory of Knowledge," Journal for Critical Education Policy Studies 05(02), The Institute for Education Policy Studies, http://www.ieps.org.uk/, $2007 . \quad$ Retrieved online: http://www.jceps.com/?pageID=article\&articleID=100 